\title{
The humanized care of the multidisciplinary team of a Mixed Unit, Pernambuco, 2021
}

\author{
Elisângela Vieira da Rocha ${ }^{1}$, Maria de Fátima de Souza Chaves ${ }^{2}$, Andrezza Fabianni Pedrosa dos \\ Santos Lima $^{3}$, Emilly Tainá Batista da Silva ${ }^{4}$, Emivaldo Batista da Silva ${ }^{5 *}$, Joana Bulhões Alvares da \\ Silva Lima ${ }^{6}$, Valquiria da Silva Gomes ${ }^{7}$, Valéria Correia Barbosa ${ }^{8}$, Marta Isabela dos Santos ${ }^{9}$, \\ Emanuella Souza Bacelar ${ }^{10}$, Anne Mayara do Carmo Matias de Lima ${ }^{11}$, Michelle Lúcia de Melo", \\ Emanuella Barros de Souza Oliveira Alvares ${ }^{13}$
}

\section{1,2 Department of Social Work, University Center of Vitória de Santo Antão (UNIVISA), Pernambuco}

3 Department of Nutrition, University Center of Vitória de Santo Antão (UNIVISA), Vitória de Santo Antão, Pernambuco, Brazil

4 Department of Biomedicine, Post-Graduation in Laboratory Clinical Microbiology (ASCES- UNITA) Caruaru - PE

5,6,10 Department of Pharmaceutical Sciences, University Center of Vitória de Santo Antão - (UNIVISA) Vitória de Santo Antão, Brazil.

7,8 Nursing Department, University Center of Vitória de Santo Antão - (UNIVISA), Vitória de Santo Antão, Brazil.

9 Department of Physiotherapy, Federal University of Pernambuco - UFPE, Recife

11 Department of Dentistry, Tiradentes University Center (UNIT-PE) Recife - PE

12 Department of the Bachelor of Law Course, Facol University Center (UNIFACOL)

13 Department of Biology, Center for Biological Sciences, Professor of the Degree Course in Biology, University Center of Vitória de Santo Antão (UNIVISA), Vitória de Santo Antão, Brazil

E-mail adresses: elisangela.2018230015@univisa.edu.br1 (Elisângela Vieira da Rocha), maria.201813007@univisa.edu.br2 (Maria de Fátima de Souza Chaves), andrezzafpslima@hotmail.com3 (Andrezza Fabianni Pedrosa dos Santos Lima), emilly.taina@hotmail.com4 (Emilly Tainá Batista da Silva), emivaldobatista4@gmail.com5 (Emivaldo Batista da Silva), joanafarmacia2018@gmail.com6 (Joana Bulhões Alvares da Silva Lima), valeriacorreiabarbosa2@gmail.com7 (Valéria Correia Barbosa), kilgomessilva10@gmail.com8 (Valquiria da Silva Gomes),marta.isabela@ufpe.br9 (Marta Isabela dos Santos), mannubacelar@gmail.com10 (Emanuella Souza Bacelar), anne1996.am@gmail.com11 (Anne Mayara do Carmo Matías de Lima), michellemelopsi@hotmail.com12 (Michelle Lúcia de Melo), emanuella.barros@hotmail.com13 (Emanuella Barros de Souza Oliveira Alvares).

${ }^{*}$ Corresponding author

\section{To cite this article:}

Rocha, E.V.; Chaves, M.F.S.; Lima, A.F.P.S.; Silva, E.T.B.; Silva, E.B.; Lima, J.B.A.S.; Gomes, V.S.; Barbosa, V.C.; Santos, M.I.; Bacelar, E.S.; Lima, A.M.C.M.; Melo, M.L.; Álvares, E.B.S.O. The humanized care of the multidisciplinary team of a Mixed Unit, Pernambuco, 2021. International Journal of Sciences. Vol. 3, No. 1, 2022, pp.63-68. ISSN 2763-5392.

Received: 11 24, 2021; Accepted: 12 26, 2021; Published: 01 15, 2022

\begin{abstract}
This research aims to present the process of humanized care of the multidisciplinary team implemented in the Mixed Unit Maria Gaião Guerra, located in the municipality of Glória do Goitá - PE, experienced by students duly enrolled in the Bachelor of Social Work course of the University Center of Vitória de Santo Antão - UNIVISA. The methodology was initially based on the observation made during the experience of the curricular component of Supervised Internship II, carried out in the Mixed Unit Maria Gaião Guerra, located in the municipality of Glória do Goitá - PE, regarding the process of humanized care of the multidisciplinary team implemented in the health equipment under study. Based on the National Humanization Policy and the National Health Promotion Policy, correlating the importance of both for the qualification of the practice and health promotion.
\end{abstract}

Keywords: Humanized Care; Hospital Humanization; Public Health.

\section{Introduction}

According to the National Humanization Policy (2013), called Humaniza SUS - Unified Health System, humanizing translates into including the differences between management and the care process. This change is not caused by individuals 
2 Rocha, E.V.; Chaves, M.F.S.; Lima, A.F.P.S.; Silva, E.T.B.; Silva, E.B.; Lima, J.B.A.S.; Gomes, V.S.; Barbosa, V.C.; Santos, M.I.; Bacelar, E.S.; Lima, A.M.C.M..; Melo, M.L.; Álvares, E.B.S.O. The humanized care of the multidisciplinary team of a Mixed Unit, Pernambuco,

or groups isolated, but collectively and sharedly, including and stimulating new forms of care and work organization.

According to the CFESS (2009) the National Program for humanization of Hospitaller Care (PNHAH) was prepared in 2001 by the Ministry of Health in order to promote the culture of humanized care in the health area, in 2003, being transformed international Politic humanization (PNH) expanding its dimension and thus contemplating management and care.

In relation to the National Humanization Policy (PNH),it canbe recognized as a public policy of the SUS, which serves to directly assist it in the process of implementing users' rights, directed to the activation of devices that in order to favor and ensure the proper adoption of humanization actions in health care in Brazil , acting based onclinical, ethical and political orientations, contributing in a shared way, in the creation of solidarity bonds, collectives promoting care, attention, welcoming users and articulationbetween the municipal, state and federal spheres (BRASIL, 2010).

When dealing with actions such as the adoption of humanized actions in health equipment, implementation of users' rights and adoption of sustainable management, the Social Worker becomes a fundamental professional in the composition of multidisciplinary health teams that can be found in several Program dthe Unified HealthSystem (SUS). This professional isresponsible for welcoming the patient, guiding the patient and family members, in order to ensure the insertion of family members in the diagnosis, treatment and cure process. Therefore, he assumes the role of facilitator of the intrafamily relationship (CFESS, 2008).

The care to users when it occurs in the hospital environment should be based solely on public health policies, published and recognized by the competent agencies, active professionals and the users themselves, providing anticipating any recommendation of intervention, as well as the identification of the methods adopted for each protocol, diagnosis and treatment. In this context, values such as ethics, recognition and respect must be developed by this multidisciplinary team. All need to be recognized as prominent participants in creating a human and inclusive environment (VASCONCELOS \& PEIXOTO, 2018, p. 33).

Moreover, the critical eye should be adopted and developed by each professional who constitutes the team in operation, thus ensuring an analysis for each demand, establishing the necessary support to users and their families as members of a society, ensuring their rights and opportunistic throughout their stay the proper support (BRASILIA 2009).

According to studies evidenced by Barbosa \& Silva (2017), during the process of humanized care, health professionals, especially nursing, provide care closer to the patient being able to understand their weaknesses and irritations, offering necessary information to the team about the physical and mental state of the user.

Once the humanized care is described as being, a care that considers the holistic character, which values all the social expressions that the user brings with him or is involved, recognizing the particularities of each one, acting with equity and equality within his individuality, ensuring the principles established by the Unified Health System (BRASIL 2010). It is necessary to present the process of humanized care of the multidisciplinary team implemented in the Mixed Unit Maria Gaião Guerra, located in the municipality of Glória do Goitá PE, experienced by students duly enrolled in the Bachelor of Social Work course of the University Center of Vitória de Santo Antão - UNIVISA.

\section{Methodology}

The methodology was initially based on qualitative observation, in order to produce contextual explanations of studied phenomena. The research was carried out during the experience of the curricular component of Supervised Internship II, carried out in the Maria Gaião Guerra Mixed Unit, located in the municipality of Glória do Goitá - PE, regarding the process of humanized care of the multidisciplinary team implemented in the health equipment under study. Based on the National Humanization Policy and the National Health Promotion Policy, correlating the importance of both for the qualification of the practice and health promotion. Toda multi-professional team, management and administrative technicians participated in this construction (GUERRA, 2018).

\section{Coverage area}

The municipality of Glória do Goitá is located in the State of Pernambuco, in the territory of the Zona da Mata Norte, with approximately 30,847 inhabitants with a territorial area of $234,214 \mathrm{~km}^{2}$. The municipal office has a temperature ranging from $21^{\circ} \mathrm{C}$ to $32^{\circ} \mathrm{C}$, with remnants of Atlantic forest. Its Human Development Index was 0.640 in 2010 (IBGE, 2017). The average concentration of income distribution has a Gini index of 0.5287 (UNDP, 2010) with $16.55 \%$ of the population on the poverty line, denoting marked social inequality (IBGE, 2010). (Figure 01).

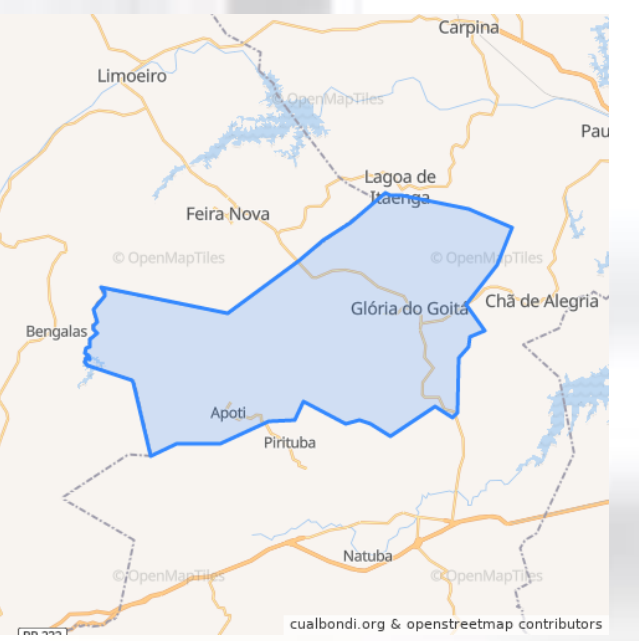

Figure 01. Municipality of Glória do Goitá/PE. Source: https://cualbondi.org/br/a/r303732/gloria-do-goita/ 
The Maria Gaião Guerra Mixed Health Unit (CNPJ: 11.049.814/0001-37), located at Rua Me. From God, S/N, Centro, Glória do Goitá, CEP: 55620-000, Pernambuco, is composed of a multidisciplinary team: doctors, nurses, nursing technicians, psychologist, nutritionist, pharmacist. The operation corresponds to 24-hour emergency and emergency care, laboratory tests for outpatient consultations. In the internal structure, there are separate beds for children, men and women, as well as rooms for puerperal women, pregnant women, newborns, delivery room, two rooms for the first visits to symptomatic patients of covid-19, x-ray room.

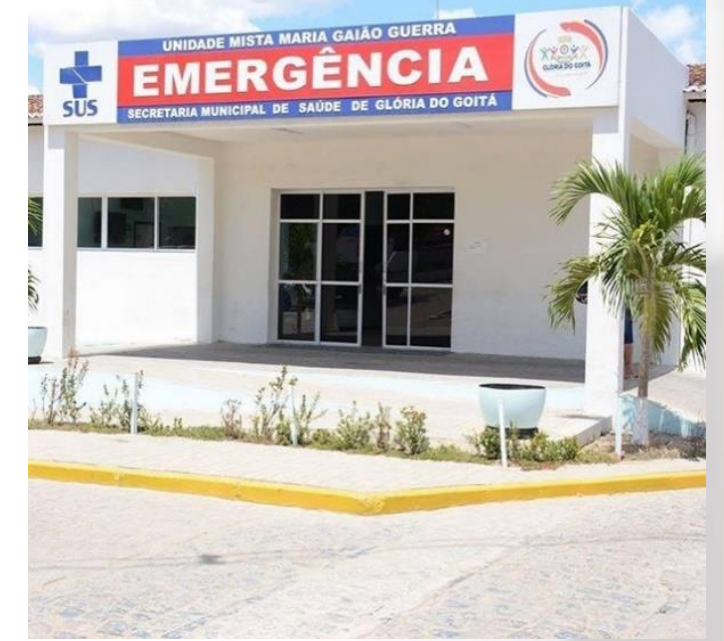

Figure 2. Source : https://cualbondi.org/br/a/r303732/gloria-dogoita/

In addition, it is also noteworthy the provision of ambulances to perform the transfer of patients to the reference clinical centers, these being located in the metropolitan region or in surrounding municipalities.

In relation to the care of users, they carry with them some particularities, such as violation of rights, so it is necessary a humanized care/reception focused on the patient's well-being, treatment effectiveness and professional qualification. These users are patients who require emergency care.

The Mixed Unit is a low complexity health equipment that welcomes spontaneous demands from its patients. The emergency works through spontaneous demand, being open door when there is a need to refer the patient to another service.

In relation to the humanization process implemented in the unit, it is noted that the responsible sector follows the recommendations indicated in the National Policy. However, some professionals have resistance in the adoption of some strategies indicated by this policy directly linked to the care process.

\section{Results and Discussion}

Changes in the form of care can be provided from the implementation of the National Humanization Policy (NHP), which is recognized as a mechanism considered a means of intervention by the Ministry of Health, in order to ensure the improvement of the quality of health care. This understanding occurred on a larger scale, based on the coordinating mobilization by organized civil society during the 1970s, when it was a discussion directed at the mental health service, which used the declaration of human rights as a basis (PNH, 2020).

Faced with the problem presented, it was thought to create a project in order to meet the needs of the user at the necessary moment of the intervention. The social service professional acts in the various expressions of the social issue, that is, he will act in what is the result of a condition of inequality, of contradictions of the capitalist system in the high rates of social inequality.

The challenges faced by social workers on the social issue are diverse and to address this theme is to explore obscure issues and by realities in transformations. Therefore, knowledge is an important work tool of this professional, because it will enable it to truly understand the possibilities of the various interventions.

In the hospital context, the social service professional is the mediator between the doctor and the patient aiming at better conditions for the same, with the aim of ensuring the well-being for the patient and his/her family members.

Thus, it is believed that we must necessarily have a vision of what is up to us, on the threshold of our private attributions and the actions we develop in collective work in health, without forgetting our ethical-political commitment to the population.

In relation to the field of action of the Social Worker health, itis prominent that "Parameters for the Performance of the Social Worker in Health Policy" (2010), can be used and/or applied. This document is considered a legal instrument, which will enable professionals to conduct the demands encountered along the way.

'In addition to these documents directly linked to our profession, a multitude of laws provides for the exercise of the activities of health workers at the general level, through which we are a party, as well as the various fields and health policies existing in Brazil' (idem, 2010, p. 38).

Also, according to the Ministry of Health (2010) the NHP is structured based on: Principles, Method, Guidelines and Device. Thus, we can affirm that in the process of effective subjectivity and collectivity in care and management practices in the SUS, for the commitment of the defense of citizenship rights, and specific needs of gender, ethnic - racial, sexual orientation, etc.

The health professional needs/needs to see in his patient the needs, their complaints, the difficulties encountered during the communication process, listen to this patient without interrupting him, understand that values such as ethics, respect and acceptance are essential to create a more humane and empathic environment. According to 
4 Rocha, E.V.; Chaves, M.F.S.; Lima, A.F.P.S.; Silva, E.T.B.; Silva, E.B.; Lima, J.B.A.S.; Gomes, V.S.; Barbosa, V.C.; Santos, M.I.; Bacelar, E.S.; Lima, A.M.C.M..; Melo, M.L.; Álvares, E.B.S.O. The humanized care of the multidisciplinary team of a Mixed Unit, Pernambuco, $2021 \ldots$

Backes, Lunardi and Lunardi Filho (2006).

"Perceiving the other requires a deeply human attitude. Recognizing and promoting humanization, in the light of ethical considerations, demands an effort to review, mainly, attitudes and behaviors of professionals directly or indirectly involved in patient care, which is also rooted in the Code of Ethics of Nursing Professionals (CEPE)(1), evidencing that professional codes of ethics, as an expression of value systems, explain the morality of a group, presupposing the imposition of these values, and not its questioning(2). Regarding the values of the nursing profession, the CEPE, in article three (1), guide professional practice towards respect for the life, dignity and rights of the human person, without any discrimination. More than limiting itself to a set of norms, the CEPE establishes the responsibility for the promotion of the human being in the multiple dimensions".

The hospital, when humanized, it contemplates the value of respect, dignity, the guarantee of rights and a good care/reception, among health professionals, employees, patients and family members. The relevance of this project is in expanding the humanization in the institution, so that a good reception can be carried out, and, in a primary way, the rights to the user are guaranteed.

The health equipment chosen was the Maria Gaião Guerra Mixed Unit, a site that is based on providing assistance regarding the demands in emergency situations and medical emergencies.

The Humanization Policy should be inserted in all SUS policies and programs, seeking the realization of rights in humanized work through a good reception with value in health practices, dissociating all professionals.

'For humanization to be very effective, it must be grounded to principles such as: participation of citizens in human actions that require management and attention; Interactivity between people; empathic emotions and protagonist among citizens' (REIS, 2013).

Regarding the issue related to the vulnerability situation of users and family members, some episodes of neglect could be monitored. In view of this identification, the intervention becomes necessary in order to modify the reality of the environment, promoting well-being through the team instructed to do so. In Article 2 of the Universal Declaration of Human Rights, we can observe information that indicates that rights must be respected and executed in their entirety, without distinction of groups, thus not being able to fail to provide help or care when this patient needs it (Article 135 of Decree Law No. 2,848 of December 7, 1940).

Humanization is the valorization of people, users, workers and especially health professionals. To provide access and promote the guarantee of rights to users, as well as to offer a service and human reception is to value subjects. Seeking a non-dissociation between classes and making changes that provide well-being, a better way of caring, and new ways of organizing work. The hospital, when humanized, it contemplates the value of respect, dignity, the guarantee of rights and a good care/reception, among health professionals, employees, patients and family members.

The experience of life with the practice of humanization in the health area becomes significant when this professional recognizes the importance of care, of welcoming, the desire to live humanization in its entirety.

'Every human being is composed of principles: ethical and moral. It is known that, often, the human being is out of control and some of these values are sent alongside consciousness. But what would humanization be? It is the act of the human being himself to use various techniques such as: behaviors, actions and values to be able to help the other who needs this help, that is, empathy between human beings often promote principles that qualify the relationships between health workers (NETO and CALEGARI, 2015)'.

With public policy, one must build a direct or indirect participation of civil society, aiming to ensure a right to a particular service, action or program. In Brazil, the right to health is made possible through the Unified Health System (SUS), which is universal, integral and free, offered and guaranteed to all.

Humanization originated from the SUS, with its humanist principles of: universality, integrality, equity and social participation, culminating today the main system of social inclusion in the country.

.. surgent to design a policy of humanization of healthcare in the Unified Health System - SUS understood here not only as a "program" to be applied to the various health equipment, but as a policy that operate across the SUS. (...) As a policy, it should translate principles and ways of operating in the set of relationships between professionals and users, between the different professionals, between the various health units and equipment, among the instances that constitute the SUS' (BRASIL/MS, 2003b, s/p).

In the world of the health services business, we note the overbilling and undeclared collection of some services, treatments, machinery... Contractors are usually companies in the same sector, commercial banks, entrepreneurs or people with good purchasing power.

In cases of institutions and professionals in the area, a misstep is created in the offer of universal services, because the same when guaranteed usually takes longer to achieve and in many cases, patients die in the waiting line waiting for care.

The description of the competencies of the social service professional, are based on political, economic, historical and cultural determinations that are present in the service demanded and the answers offered, based on the ethical values that underlie the practice of Social Work, structured in the Professional Ethical-Political Project, and 
on the Code of Ethics, according to MATTOS (2015) explicit in an excerpt of his speech

'... it is not individual merit, but the result of a project that is collectively constructed in services, which feeds back on the intellectual production of the profession and its political-professional organization, from the text Considerations on attributions and professional competencies of social workers today.

In addition, we seek through this activity, to guide the professional team that does not perform a humanized care and in which some practices of violation of law go unnoticed, such as: physical, verbal, psychological and sexual violence, as well as the neglect of care and care, discrimination, favoring to third parties through their services in the public and hospital environment, can be made aware of their role and their importance in promoting the quality of life of Patients.

\section{Conclusions}

Considering the experience of the practice and the monitoring of the description of the competencies of the social service professional that are based on political, economic, historical and cultural determinations that are present in the service demanded and the answers offered, based on the ethical values that underlie the practice of Social Work, structured in the Professional Ethical-Political Project, and the Code of Ethics.

To this end, it is expected that this study will, in some way, alert health professionals to the prominence of humanization in a hospital environment. Considering the form of presentation of the reception, dispensed in this study, as the most powerful to produce care in health care in the hospital environment.

In the daily conviviality of the supervised internship period, it was found that the Social Worker receives numerous types of demands, such as domestic violence, neglect with the elderly and children, social discharges, transfer of information to families, etc. requiring this professional a qualified knowledge and an immediate action in most requests.

In a "potentiated"', this professional seeks to meet the interests of users, as well as intermediate solutions when they cannot solve in that environment.

\section{Acknowledgements}

We thank God first, who allowed us to get here on this long journey and who is undoubtedly the greatest Teacher of all. Who has always cast his mercy on our journey and all along the long journey? Even with difficulties, doubts and obstacles that several times tried to keep us away from our dream, perseverance was our daily motto.

To our classmates and students; to our unforgettable and so dear and admired teachers.

A special affection to our dear advisor Emanuela Barros de Souza Oliveira Alvares, who has always been available to clarify and lead us during the realization of this research.

And to our families and to all those who, directly or indirectly, were part of our formation, of our journey, of our journey, our thank you.

\section{References}

[1] BACKES, Dirce Stein; LUNARDI, Valéria Lerch; LUNARDI FILHO, Wilson D. A HUMANIZAÇÃO HOSPITALAR COMO EXPRESSÃO DA ÉTICA. Revista Latino-americana de Enfermagem, [s. 1], v. 1, n. 14, p. 132-135, fev. 2006. Disponível em:https://www.scielo.br/j/rlae/a/dyHDHRtQTZyG pg8RJRdrpPK/?format=pdf\&lang=pt. Acesso em: 14 dez. 2021.

[2] BRASIL. Ministério da Saúde. Secretaria de Vigilância em Saúde. Secretaria de Atenção à Saúde. Política Nacional de Promoção da Saúde / Ministério da Saúde, Secretaria de Vigilância em Saúde, Secretaria de Atenção à Saúde. - 3. ed. - Brasília: Ministério da Saúde, 2010.

[3] BRASIL. Ministério da Saúde. Secretaria de Atenção à Saúde. Núcleo Técnico da Política Nacional de Humanização. Humanizas US: Documento base para gestores e trabalhadores do SUS / Ministério da Saúde, Secretaria de Atenção à Saúde, Núcleo Técnico da Política Nacional de Humanização. - 4. ed. 4. reimp. - Brasília: Editora do Ministério da Saúde, 2010. 72 p.: il. color. (Série B. Textos Básicos de Saúde)

[4] BRASIL/MS 2004: 41-55) Os termos acima citados foram retirados do Glossário Humaniza SUS e tratase de uma síntese revisada das diferentes contribuições: Adail Rollo, Adriana Miranda de Castro, Altair Massaro, Bernadeth Peres Sampaio, Eduardo Passos, Geraldo Sales, Gilberto Scarazati, José Jacson, Maria Eunice Campos Marinho, Rosana Onocko, Stella Chebli, além da Biblioteca Virtual de Saúde (BVS/MS) e SEGETES.

[5] BRASIL. Ministério da Saúde. Secretaria de Atenção à Saúde. Núcleo Técnico da Política Nacional de Humanização. Humaniza SUS: Documento base para gestores e trabalhadores do SUS / Ministério da Saúde, Secretaria de Atenção à Saúde, Núcleo Técnico da Política Nacional de Humanização. - 4. ed. 4. reimp. - Brasília: Editora do Ministério da Saúde, 2010. 72 p.: il. color. (Série B. Textos Básicos de Saúde)

[6] BRASílIA. Parâmetros para a Atuação de Assistentes Sociais na Saúde. Brasília: Conselho Federal de Serviço Social - CFESS, 2009. Disponível em:

http://www.cfess.org.br/arquivos/Parametros_para Assistentes_Sociais_na_Saude__versao_preliminar.pdf. Acesso em: 27 ago. 2021.

[7] BRASÍLIA. MINISTÉRIO DA SAÚDE. Política 
6 Rocha, E.V.; Chaves, M.F.S.; Lima, A.F.P.S.; Silva, E.T.B.; Silva, E.B.; Lima, J.B.A.S.; Gomes, V.S.; Barbosa, V.C.; Santos, M.I.; Bacelar, E.S.; Lima, A.M.C.M..; Melo, M.L.; Álvares, E.B.S.O. The humanized care of the multidisciplinary team of a Mixed Unit, Pernambuco,

Nacional de Humanização - Humaniza SUS. Disponível em: https://www.gov.br/saude/ptbr/acesso-a-informacao/acoes-e-programas/politicanacional-de-humanizacao-humanizasus. Acesso em: 14 dez. 2021.

[8] BETTINELLI, Luiz Antonio; WASKIEVIC, Josemara; ERDMANN, Alacoque Lorenzini. Humanização do cuidado no ambiente hospitalar. O Mundo da Saúde, São Paulo, v. 27, n. 2, p. 231-239, jun. 2003. Disponível em: https://bvsms.saude.gov.br/bvs/is_digital/is_0403/pd f/IS23(4)111.pdf. Acesso em: 14 dez. 2021.

[9] CONSELHO FEDERAL DE SERVIÇO SOCIAL CFESS, 2009, Brasília. Parâmetros para a Atuação de Assistentes Sociais na Saúde. Brasília: Conselho Federal de Serviço Social - CFESS, 2009. Disponível em:

http://www.cfess.org.br/arquivos/Parametros_para Assistentes_Sociais_na_Saude__versao_preliminar.pdf. Acesso em: 27 ago. 2021.

[10] CONSELHO FEDERAL DE SERVIÇO SOCIAL. Legislação e Resoluções sobre o trabalho do/a assistente social / Conselho Federal de Serviço Social - Gestão Atitude Crítica para Avançar na Luta. Brasília: CFESS, 2011. 188 p.

[11] Decreto-lei no 2.848, de 7 de dezembro de 1940 . Código Penal. Diário Oficial da União, Rio de Janeiro, 07 dez.

[12] GALliAN, Dante Mc. A (re)humanização da medicina. Psiquiatria na Prática Médica, São Paulo, v. 34, n. 4, 2002. Disponível em: http://www2.unifesp.br/dpsiq/polbr/ppm/especial02 a.htm. Acesso em: 14 dez. 2021.

[13] MATOS, Maurílio Castro de. Considerações sobre atribuições e competências profissionais de assistentes sociais na atualidade. Serv. Soc. Soc., São Paulo, n. 124, p. 678-698, dez. 2015. Disponível em: https://www.scielo.br/j/sssoc/a/zKqHPXTYyTSPvM BrGZnzgjm/?lang=pt. Acesso em: 14 dez. 202

[14] NETO, Clarindo Epaminondas de Sá. CALEGARI, Cassiano. A Humanização da Execução da Pena Privativa de Liberdade. São Paulo: Deviant. 2015.

[15] NORONHA, Daisy Pires; FERREIRA, Fontes de informação para pesquisadores e profissionais. Belo Horizonte: UFMG, 2000.

[16]POLÍTICA NACIONAL DE HUMANIZAÇÃO PNH. Brasília: Ministério da Saúde, 2013.

[17] REIS, Fernanda. Humanização na Saúde. Rio de Janeiro: Doc. 2013.

[18] Unicef. Documento Declaração Universal dos Direitos Humanos: adotada e proclamada pela assembleia geral das nações unidas (resolução 217 a III) em 10 de dezembro 1948. Disponível em: https://www.unicef.org/brazil/declaracao-universaldos-direitos-humanos. Acesso em: 14 dez. 2021.
[19] VASCONCELOS, Ana Paula Silveira de Morais; PEIXOTO, Socorro Letícia Fernandes. Hospital: lócus de atuação e formação profissional para assistentes sociais. In: LOPES, Cinthia Fonseca (org.). Competências e atribuições do/a assistente social: requisições e conhecimentos necessários. Fortaleza: Socialis Editora, 2018. p. 33-56. 